\title{
Trace Metals in Groundwater of the South Eastern Piedmont Region of Mount Cameroon: Quantification and Health Risk Assessment
}

\author{
Richard Ayuk Akoachere ${ }^{1 *}$, Edwin Ngwene Etone1, Roy Lyonga Mbua ${ }^{2}$, Marcelle Pami Ngassam³, \\ Simon Ngomba Longonje ${ }^{2}$, Pius Mbu Oben ${ }^{4}$, Regina Wotany Engome ${ }^{1}$ \\ ${ }^{1}$ Department of Geology, University of Buea, Buea, Cameroon \\ ${ }^{2}$ Department of Environmental Science, University of Buea, Buea, Cameroon \\ ${ }^{3}$ Department of Agricultural and Environmental Engineering, Pan African University/University of Ibadan, Ibadan, Nigeria \\ ${ }^{4}$ Department of Animal Sciences, University of Buea, Buea, Cameroon \\ Email: ${ }^{\star}$ r.akoachere@ubuea.cm
}

How to cite this paper: Akoachere, R.A., Etone, E.N., Mbua, R.L., Ngassam, M.P., Longonje, S.N., Oben, P.M. and Engome, R.W. (2019) Trace Metals in Groundwater of the South Eastern Piedmont Region of Mount Cameroon: Quantification and Health Risk Assessment. Open Access Library Journal, 6: e5327.

https://doi.org/10.4236/oalib.1105327

Received: March 12, 2019

Accepted: April 27, 2019

Published: April 30, 2019

Copyright $\odot 2019$ by author(s) and Open Access Library Inc.

This work is licensed under the Creative Commons Attribution International License (CC BY 4.0).

http://creativecommons.org/licenses/by/4.0/

\begin{abstract}
The South Eastern Piedmont Region of Mount Cameroon is getting increasingly populated. Groundwater is the main resource for drinking in this area; hence, the quantification of trace metals, suitability and quality of the groundwater resources for drinking, domestic and agro-industrial uses is of public and scientific concern. In this study, 10 samples were collected from 10 sites in September 2017. Field measurement of physicochemical parameters and investigation of the levels of trace metal content in groundwater was determined using Inductively Coupled Plasma Mass Spectroscopy ICP-MS. $\mathrm{R}$-mode statistical analysis has been done and traces metals elements correlated with the physicochemical parameters and cluster analysis PCA carried out. The paper also highlights and determines the average daily dose ADD, the carcinogenic risks CR and the non-carcinogenic risk hazard quotient HQ which yields the hazard indices HI. The general trend of mean trace metal concentration in the sampled groundwater was in the order of: $\mathrm{Zn}>\mathrm{Fe}>\mathrm{Al}>$ $\mathrm{V}>\mathrm{Mn}>\mathrm{Cu}>\mathrm{Cr}>\mathrm{Ni}>\mathrm{Pb}>\mathrm{As}>\mathrm{Co}>\mathrm{Cd}>\mathrm{Sb}$. All the groundwater risk indices; $\mathrm{ADD}, \mathrm{CR}, \mathrm{HQ}$ and $\mathrm{HI}$ were less than 1 in categories of insignificant health risk. The severity of metal toxicity is governed by several factors, such as dose, nutrition, age, and even life style. Therefore, this low trend might not guarantee the complete absence of human health risk. Generally, from risk assessment on trace metals using risk indices, the analyzed water samples might not be at an alarming health risk. However, due to an increasing level of environmental pollution that might be imposed by increasing human activity in this region, water sources might become a potential sink of contaminants; this is significant reason that makes constant monitoring, implementation and treatment of groundwater for drinking purposes obligatory.
\end{abstract}




\section{Subject Areas}

Geology, Hydrology, Environment-Science

\section{Keywords}

Trace-Metal, Assessment, Pollution-Indices, Health-Risks, Environmental-Pollution, Mount-Cameroon

\section{Introduction}

This study area is situated between $4.2667^{\circ}-4.8417^{\circ} \mathrm{N}$ and $9.3333^{\circ}-9.3694^{\circ} \mathrm{E}$ at the foot of Mount Cameroon at an elevation of $570-860 \mathrm{~m}$ above mean sea level within a surface area of $270 \mathrm{~km}^{2}$ as shown in Figure 1 . The presence of trace metal species in groundwater can be of geogenic or anthropogenic origins. The constituents present may pose many health risks to human and other life when they exceed the maximum contamination levels. Because of the absence of treatment of groundwater before drinking in the piedmont regions of Mount Cameroon, it is mandatory to assess the trace metal content, and to keep regular drinking water monitoring programs. Thus the objective of this study is to examine and highlight the levels of twelve metals in spring sources in this region of Cameroon. The paper also reveals the correlation coefficients between

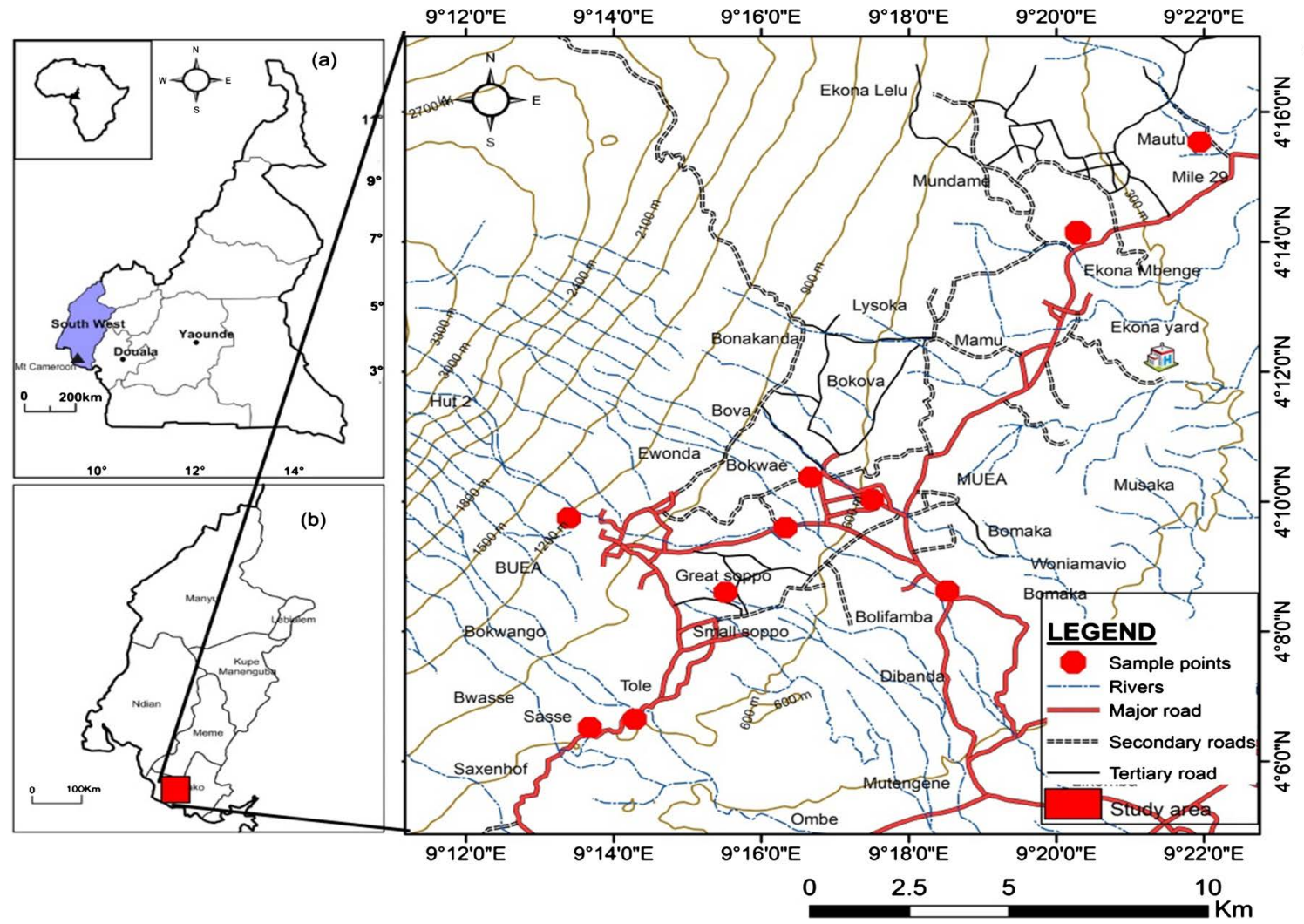

Figure 1. Location map for measurements and sample collection: Piedmont region of mount Cameroon. 
the analyzed parameters, the estimate of the degree of metal contamination hazards and pollution indices. The South Eastern Piedmont region of Mount Cameroon has numerous institutions of higher learning, administrative offices and Water bottling companies supplying the nation and exported to neighboring countries (Tchad, Nigeria, Equatorial Guinea and Gabon). Also it is an agro-industrial production zone of banana, palm oil, pawpaw, tomatoes water melon and pineapple, all of which are exported and rely on groundwater. The evaluation of the trace metal content of groundwater in this region is a vital necessity for Cameroonian and international concerns as to the quality of the exported products. The presence of the above institutions and agroindustries has led to unprecedented population growth and urbanization around this area resulting in a high demand for water that has now exceeded supply. The consequence is a greater exploitation of groundwater resources, which is the only available and reliable water source in this area for drinking, agricultural and industrial purposes [1]. The heavy metal quality of spring water that is exploited for consumption by more than $80 \%$ of inhabitants of this area is unknown. Thus a plethora of health risks associated with elevated trace metals concentrations in groundwater and soils around Mt. Cameroon respectively would arise if the trace metal concentrations of groundwater in this area is high [2] [3].

Trace metals are chemical components found in low concentrations, in mass fractions of ppm or less, in water, organisms and soil [4]. Some trace metals are essential as micronutrients $\mathrm{Cu}, \mathrm{Fe}, \mathrm{Mn}, \mathrm{Ni}$ and $\mathrm{Zn}$ for life processes in plants and microorganisms, while others $\mathrm{Cd}, \mathrm{Cr}$ and $\mathrm{Pb}$ have no known physiological activity, but are proven detrimental beyond a certain limit which is very much narrow for some elements like $\mathrm{Cd} 0.01 \mathrm{mg} / \mathrm{L}, \mathrm{Pb} 0.10 \mathrm{mg} / \mathrm{L}$ and $\mathrm{Cu} 0.050 \mathrm{mg} / \mathrm{L}$ [5]. These toxic metals, unlike some organic substances, are not metabolically degradable and have the tendency to bio-accumulate in tissues of living organisms over time which can cause death or serious health threats [6] [7].

Health risk assessment involves four steps: Hazard identification, dose-response assessment, exposure assessment, and risk characterization. Trace metals are naturally part of the environment and can be found in soils and rocks and also dissolved in rivers, streams and groundwater. Volcanic activities, domestic, agricultural, medical and technological applications have led to the wide distribution of trace metals into the environment; raising concerns over their potential effects on human health and the environment. The piedmont region of mount Cameroon, where numerous spring, streams and rivers around Fako take their rise is dominantly made up of overlapping lava flows of alkaline basalt composition, with a lesser but probably significant proportion of pyroclastic [8] [9].

Water is one of the essentials that support all form of animal and plant life [10] and it is generally obtained from two principal natural sources; Surface water such as fresh water lakes, rivers and streams and groundwater such as springs and well water. Groundwater comes into contact with rocks (alkaline basalts and pyroclastics) and their weathering products, soils. By ion exchange, precipitation, dissolution or mixing, trace metal ions contained in the rocks are introduced into the wa- 
ter. These metals exist in water as colloidal, particulate and dissolved species [11]. Metallic elements have a significant role in increasing the degradation of water quality through human activities; industrial-household wastes, thermal power plants, mining, exhaust emissions, application of fertilizers, pesticides and insecticides.

\subsection{Climate}

The study area experiences two distinct seasons: a rainy season that begins in April and ends in October with a high annual rainfall between $3000-5000 \mathrm{~mm}$, and a dry season that begins in November and ends in March [12] [13]. Daily temperatures range from $17^{\circ} \mathrm{C}-34^{\circ} \mathrm{C}$ annually.

\subsection{Hydrology and Hydrogeology}

The area is characterized by a hilly topography, a dense network of springs, streams and high humidity. Due to the fact that tectonics associated with volcanism creates fracturing and faulting that runs over long distances, the formations of the piedmont regions low-lying besides the volcanic relief have deep joints, fractures, and faults, which because of their abundance and connectivity can retain large volumes of running water in underground channels that surge out down slope as large springs [1] [14] [15]. Mt Cameroon is made up of unwelded scoria or pyroclastic materials that are porous and therefore make up good aquifers with an enormous water-holding capacity [1]. Hydrogeologically, the area is made of admixtures of various layers of volcanics fractured massive basaltic rocks with serious aquiferous potentials found mainly in fractures. At various hill sides where the overlying more permeable formations and less permeable formations are crosscut by topography or where fractures are exposed on the surface, springs occur. Also, at the lower slopes where impermeable massive basaltic lava flows or strata outcrop on the surface, springs emerge at the top of the impervious or impermeable strata [16]. This area has three principal water service providers: Camerounaise Des Eaux, CDE, Community Water Schemes CWS and private boreholes, $\mathrm{BH}$.

\subsection{Geology}

Mount Cameroon is an elliptical shaped strato-volcano approximately $4095 \mathrm{~m}$ above mean sea level and forms part of the Cameroon Volcanic Line, CVL [18]. This line is made up of 12 main volcanic centres with ages ranging from $51.8 \mathrm{Ma}$ to the Present [19] [20]. The volcanic rocks of Mt Cameroon with the exception of the nephelinite series of Mt. Etinde are typically alkaline. The lithological sequence of the differentiated alkaline series is complete and includes basaltic lavas (alkali basalts, picrites and hawaiites), intermediate lavas; mugearites and benmoreites, and felsic lavas; phonolites, trachytes, and alkali rhyolites. The general geology of Mt Cameroon is represented by a Precambrian metamorphic basement; schists and gneisses intruded by granite, diorites [21]. The basement is covered by cretaceous to quaternary sediments, observable in the Bomana maar at the NW of the massif [22] [23] as shown in Figure 2(a) and Figure 2(b). 

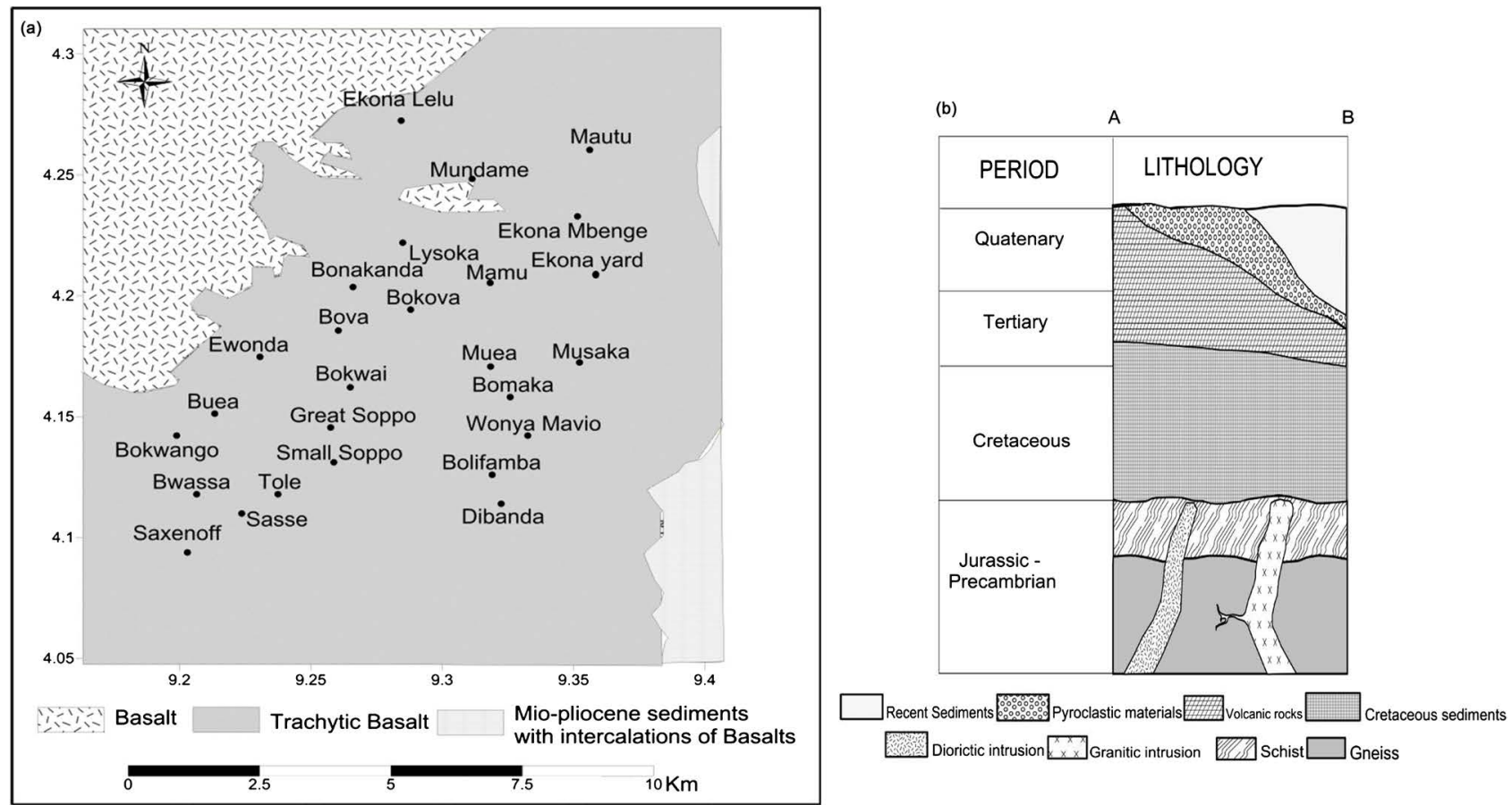

Figure 2. (a) Geologic map of study area made up of 3 rock types; trachyte, basalt and miopliocene sediments with intercalations of basalt. (b) Lithostratigraphic section showing metamorphic basement, schists and gneisses intruded by granite, diorites and overlain by Cretaceous sediments, volcanic rocks pyroclastic materials and weathered sediments.

\section{Materials and Methods}

\subsection{Sample Collection, Pre-Treatment and Chemical Analysis}

Ten groundwater samples were collected from 10 pre-selected springs. Site selection was based on spatial distribution of the springs, population and location of agro-industries. At each site, groundwater temperature, electrical conductivity and $\mathrm{pH}$ value were measured in situ, using the portable field $\mathrm{pH}, \mathrm{EC}$ and TDS meters presented in Table 1.

Prior to sampling, the pre-cleaned sample bottles were rinsed with the sample water. The spring water was withdrawn with the use of a $50 \mathrm{ml}$ syringe, and then filtered through the $0.2 \mu \mathrm{m}$ mixed cellulose ester filter into $50 \mathrm{ml}$ high-density polyethylene HDPE containers. The sample was preserved by acidifying to $\mathrm{pH}<$ 2 by adding nitric acid and sealed using a permanent tape. The samples were labelled and put into the sample bottle collection bag. The filtered groundwater samples were later shipped to the Activation laboratory in Canada for trace metal analysis by Inductive Coupled Plasma Mass Spectrometer ICP-MS.

\subsection{Questionnaire Administration}

A total of one thousand questionnaires were administered. One hundred randomly issued to households at each sampling location and assisted in filling by field workers. Population subgroups were investigated in seven main categories; area, gender, age, body weight, water source, daily intake and longevity of use. However, since trace metals concentrations were not measured in water drunk 
Table 1. Field Equipment, Softwares, their specifications and functions used in the study.

\begin{tabular}{|c|c|c|}
\hline Equipment/Softwares & Specifications & Functions \\
\hline Bike & Commercial Bikes (Bensikin) & To transport fieldworkers to wells \\
\hline GPS & GARMIN GPSMAP 60 csx & To measure longitude, latitude and elevation of wells \\
\hline EC Meter & Hanna Hi 98304/Hi98303 & To measure Electrical Conductivity of water. \\
\hline pH Meter & Hanna Hi 98127/Hi98107 & To measure $\mathrm{pH}$ of water. \\
\hline Measuring Tape & Weighted Measuring Tape & Measurement of well diameter and depth. \\
\hline Digital Thermometer & Extech $39240\left(-50^{\circ} \mathrm{C}\right.$ To $\left.200^{\circ} \mathrm{C}\right)$ & To measure water temperature \\
\hline Total Dissolved Solid & Hanna HI 96301 & To measure Total dissolved solids \\
\hline Water sampler & Gallenkampf $500 \mathrm{ml}$ & To collect water sample from well \\
\hline Syringe & 50 Ml, 100 Ml Polystyrene & Acidification and filtration of sample \\
\hline Nitric acid & 98\% Pure Nitric Acid & Sample preservation by acidifying to $\mathrm{pH}<2$ \\
\hline Filter & Cellulose Ester Filter $0.2 \mu \mathrm{m}$ & Filtration of sample \\
\hline Sample bottles & Polyethylene (HDPE) $50 \mathrm{ml}$ & To hold sample for onward transmission to laboratory \\
\hline Sealing Tape and marker & Permanent Tape and marker & Sealing of sample bottle and labeling for transmission to the laboratory \\
\hline IBM SPSS Statistics & Version 24.0 & Statistical analysis for PCA \\
\hline Global Mapper & Version 11 & GIS Geolocation of wells \\
\hline Surfer Golden Software & Version 12 & GIS plotting contours for spatial distribution \\
\hline
\end{tabular}

away from home, exposure away from home was estimated by assuming equal concentrations at home and away. Dietary exposure due to use of drinking water in hot or cold beverages and food items such as; food, breast milk, soups was not determined. The family members of respondents (various ages) were weighed using a Taylor medical weighing balance.

\subsection{Human Health Risk Assessment}

Human health risk assessment is considered as the characterization of the potential adverse health effects of humans as a result of exposures to environmental hazards and the processes of estimating the health effects that might result from exposure to carcinogenic and noncarcinogenic chemicals [24]. This process employed engineering/science tools and statistics to identify and measure hazards, determine possible routes of exposure, and finally use that information to calculate a numerical value to represent the potential risk [25]. The risk assessment process as proposed by the US Environmental Protection Agency consists of four steps [26]. These steps include: 1) Hazard identification, 2) Exposure assessment, 3) Dose response/toxicity assessment and 4) Risk characterization.

\subsubsection{Hazard Identification:}

Involves the identification of the chemical of concern and documenting its toxic effects on human beings after field mapping. It also involves the characterization of potential contaminants and their relative mobilities [27] [28] as presented in Table 2. 
Table 2. Trace metals and their effects.

\begin{tabular}{cr}
\hline Component & Toxicity effects [29] \\
\hline $\mathrm{Zn}$ & Zinc suppresses copper and iron intake causing peripheral neuropathy. \\
$\mathrm{Co}$ & Active in vitamin B12 and in chemical reactions. Excess causes hearth failures. \\
$\mathrm{Cu}$ & Excess leads to acute gastrointestinal problems \\
$\mathrm{Cr}$ & Excess may result in renal failures. Excess of Cr ${ }^{+6}$ is carcinogenic. \\
$\mathrm{Mn}$ & Manganese toxicity result in neurological disorder; manganism, with symptoms of tremors \\
$\mathrm{Cd}$ & Cadmium compounds are known human carcinogens. \\
$\mathrm{V}$ & Vanadium causes albumin in urine \\
$\mathrm{Ni}$ & Nickel is carcinogenic and causes neurological deficits \\
$\mathrm{As}$ & Arsenic causes cancer of the skin, lungs, liver and bladder. \\
$\mathrm{Sb}$ & Antimony causes gastrointestinal problems, kidney damage or liver damage \\
$\mathrm{Al}$ & Aluminium causes neurotoxicity. \\
$\mathrm{Pb}$ & Lead is a carcinogen affecting every organ and system in the body. \\
\hline
\end{tabular}

\subsubsection{Exposure Assessment}

This is the process of measuring or estimating the intensity, frequency and duration of human exposures to an environmental agent [27]. The main exposure pathway taken into consideration in this study was intake of the metals through water consumption. The daily environmental exposures to metals were assessed for carcinogenic and non-carcinogenic elements.

The intakes of metals through ingestion of groundwater were calculated using Equation (1) [29].

$$
A D D=\frac{C \cdot I R \cdot E D \cdot E F}{B W \cdot A T \cdot 360}
$$

where;

- $A D D s$ is Exposure duration ( $\mathrm{mg} / \mathrm{kg}$-day)-The Average Daily Dose (ADD) of the contaminant through water pathway indicates the quantity of chemical substance ingested per kilogram of body weight per day.

- $C$ is Concentration of contaminant in the environmental media (e.g., $\mu \mathrm{g} / \mathrm{L}$, $\mathrm{mg} / \mathrm{L})$.

- $I R$ is Ingestion rate per unit time (e.g., $\mathrm{mg} /$ day or $\mathrm{L} /$ day).

- $E F$ is Exposure frequency (day/year).

- $E D$ is Exposure duration (years).

- $B W$ is Body weight of receptor (kg).

- $A T$ is Averaging time = life expectancy (years) 365 is the conversion factor from years to days.

For non-carcinogenic effects, $A T=E D$ in days; carcinogenic effect, $A T=70$ years or 25,550 days [29].

\subsubsection{Dose-Response/Toxicity Assessment}

This is the quantitative relationship that indicates the contaminants degree of 
toxicity to exposed species. It also involves the identification of the toxicity criteria used to evaluate human health risk associated with the chemical of concern in the study area. The amount of chemical that can affected human health is estimated. The Reference Dose RfD is used for non-carcinogen risk.

\subsubsection{Risk Characterization}

This is the final phase of the risk assessment process. In this phase, cumulative exposure and dose-response assessments are integrated to yield probabilities of effects occurring in human beings under specific exposure conditions and time scales. Also incorporated is information from hazard identification, exposure assessment, toxicity assessment and risk estimation to evaluate the potential risk to residents.

\subsubsection{Carcinogenic Risk Assessment}

Carcinogenic risks were determined by calculating the potential of an individual to develop cancer as a result of cumulative exposure to each potential carcinogen over a lifetime. For carcinogen, identified by a weight-of-evidence classification of the chemical [24]. The estimated daily dose and the cancer slope factor are multiplied together to find the lifetime cancer risk posed by the chemical. Cancer slope factors are estimates of carcinogenic potency and were used to relate estimated daily dose of the trace metal over a lifetime exposure to the lifetime probability of excess tumors Equation (2) [24] [30] [31].

$$
C R=A D D \cdot S F
$$

$C R$ is the excess probability of developing cancer over a lifetime as a result of exposure to a contaminant or carcinogenic risk. It is unit less; $S F$ is the slope factor of the contaminant $[\mathrm{mg} / \mathrm{kg} / \mathrm{d}]^{-1}$.

\subsubsection{Non Carcinogenic Risk Assesment}

Non-carcinogenic hazards are characterized by the hazard quotient (HQ). $H Q$ is a unitless number that is expressed as the probability of an individual suffering an adverse effect. To estimate noncarcinogenic risk, the hazard quotient (HQ) was calculated using Equation (3) [32].

$$
H Q=\frac{A D D}{R f D},
$$

$R f D$ is the reference dose $\mathrm{mg} / \mathrm{kg} / \mathrm{d}$. It represents a toxicity index of a daily exposure to the population in comparison to a safe level of exposure orally over a lifetime [33].

\subsubsection{Harzard Index (HI)}

Harzard index (HI) is the toxic risks due to all the potentially hazardous substances present in the same media simultaneously [26]. Since more than one toxicant is evaluated, the interactions of all the toxicants were considered and assumed to be cumulative. Thus, the $H I$ was calculated by summing all the HQ for all toxicants, Equation (4) [32]. 


$$
H I=\sum_{i=1}^{n} H Q_{i}
$$

\section{Results and Discussion}

\subsection{Field Measured Physicochemical Parameters}

Field physicochemical parameters EC, pH, TDS and Temperature were measured and presented in Table 3. EC ranged from $128-290 \mu \mathrm{S} / \mathrm{cm}$, pH from 6.2 6.9, TDS from 85.8 - $194.3 \mathrm{mg} / \mathrm{L}$ and temperature from $18.5^{\circ} \mathrm{C}-22.9^{\circ} \mathrm{C}$.

\subsection{Body Weight and Water Intake}

The ranges of measured mean body weights and the ranges of mean daily water intakes from 1000 questionnaires; 100 households per location in the various age groups presented in Table 4, was used to determine the various risk and hazard indices.

\subsection{Trace Metals Concentrations in Groundwater at Various Locations of Study Area}

The results for ten water samples of trace metal analysis ICP-MS are presented in Table 5. The concentrations of thirteen trace metals; $\mathrm{Zn}, \mathrm{Pb}, \mathrm{Co}, \mathrm{Cu}, \mathrm{Cr}, \mathrm{Mn}$, $\mathrm{Cd}, \mathrm{V}, \mathrm{Fe}, \mathrm{Ni}, \mathrm{As}, \mathrm{Sb}, \mathrm{Al}, \mathrm{Mn}$, and $\mathrm{Pb}$ were evaluated. All concentrations of these trace metals are below the WHO allowable limits and as such will not cause any immediate harm to consumers. However, the cumulative effects of long term consumption of these trace metals in the groundwater necessitated a health risk assessment.

Groundwater trace metal concentrations detected in samples varied within the

Table 3. Field determined physicochemical parameters; electrical conductivity (EC), pH, total dissolved solids (TDS) and temperature of groundwater in study area.

\begin{tabular}{ccccccc}
\hline & $\mathrm{N}$ & $\mathrm{E}$ & $\mathrm{E} \mathrm{C} \mu \mathrm{S} / \mathrm{cm}$ & $\mathrm{PH}$ & $\mathrm{TDS} \mathrm{mg} / \mathrm{L}$ & $\mathrm{Temp}{ }^{\circ} \mathrm{C}$ \\
\hline UPPERFARMS & 9.2232222 & 4.162472 & 128.0 & 6.2 & 85.8 & 18.5 \\
SASSE & 9.2279444 & 4.108667 & 190.0 & 6.6 & 127.3 & 21.5 \\
TOLE & 9.2380833 & 4.110806 & 209.0 & 6.8 & 140.0 & 21.1 \\
SANDPIT & 9.2586111 & 4.143361 & 245.0 & 6.7 & 164.2 & 21.5 \\
BONDUMA & 9.2721389 & 4.159972 & 207.0 & 6.8 & 138.7 & 22.7 \\
BWITEVA & 9.2778056 & 4.172889 & 290.0 & 6.8 & 194.3 & 21.4 \\
MUEA & 9.29175 & 4.167167 & 258.0 & 6.9 & 172.9 & 22.1 \\
MILE 16 & 9.3087222 & 4.143722 & 248.0 & 6.9 & 166.2 & 22.9 \\
EKONA & 9.338 & 4.236 & 270.0 & 6.7 & 180.9 & 22.8 \\
MAUTU & 9.3656944 & 4.258972 & 271.0 & 6.7 & 181.6 & 22.8 \\
& Min & & 128.0 & 6.2 & 85.8 & 18.5 \\
& Max & & 290.0 & 6.9 & 194.3 & 22.9 \\
& Mean & & 227.8 & 6.7 & 152.6 & 21.6 \\
\hline
\end{tabular}


Table 4. Mean Body weight BW, age-group Y and oral water intake WI.

\begin{tabular}{|c|c|c|c|c|c|c|c|c|c|c|}
\hline \multirow{2}{*}{$\begin{array}{c}\text { AGE } \\
\text { WEIGHT }\end{array}$} & \multicolumn{2}{|c|}{$0-5 \mathrm{Y}$} & \multicolumn{2}{|c|}{$6-10 Y$} & \multicolumn{2}{|c|}{$11-15 Y$} & \multicolumn{2}{|c|}{$16-20 Y$} & \multicolumn{2}{|c|}{$21-25 Y$} \\
\hline & BW (Kg) & WI (L) & BW $(\mathrm{Kg})$ & WI (L) & BW $(\mathrm{Kg})$ & WI (L) & BW (Kg) & WI (L) & BW (Kg) & WI (L) \\
\hline UPFARMS & $4.5-15$ & $0.5-1$ & $19-30$ & $0.5-2$ & $32-55$ & $1.0-4$ & $42-85$ & $1.0-5$ & $57-85$ & $1.0-5$ \\
\hline SASSE & $4.5-15$ & $0.25-2$ & $18-33$ & $0.5-3$ & $39-52$ & $1.0-3$ & $45-62$ & $1.0-5$ & $60-83$ & $1.0-5$ \\
\hline TOLE & $4.5-12$ & $0.25-2$ & $16-37$ & $1.0-2$ & $30-50$ & $1.0-2$ & $54-65$ & $1.0-5$ & $60-70$ & $1.0-3$ \\
\hline SANDPIT & $5.5-14$ & $0.25-5$ & $19-32$ & $0.5-1.5$ & $32-55$ & $1.0-2$ & $40-60$ & $1.0-3$ & $52-71$ & $1.0-5$ \\
\hline BONDUMA & $5.5-12$ & $0.25-1$ & $18-37$ & $1.0-3$ & $40-51$ & $1.0-3$ & $50-61$ & $1.0-5$ & $60-72$ & $1.0-5$ \\
\hline BWITEVA & $5.0-12$ & $0.25-1.5$ & $25-41$ & $1.0-5$ & $45-53$ & $1.0-3$ & $56-63$ & $1.0-5$ & $60-70$ & $1.0-5$ \\
\hline MUEA & $4.6-12$ & $0.25-1$ & $18-37$ & $0.5-2.5$ & $39-84$ & $1.0-2$ & $50-65$ & $1.0-5$ & $60-70$ & $1.0-3$ \\
\hline MILE 16 & $5.0-19$ & $0.25-1.5$ & $21-65$ & $0.5-2$ & $37-55$ & $1.0-3$ & $56-65$ & $1.0-5$ & $58-88$ & $1.0-5$ \\
\hline EKONA & $7.2-15$ & $0.25-1$ & $20-31$ & $1.0-2$ & $45-56$ & $1.0-2$ & $57-60$ & $1.0-2$ & $62-70$ & $1.0-5$ \\
\hline MAUTU & $3.9-16$ & $0.25-2$ & $18-39$ & $1-1.5$ & $40-75$ & $1.0-3$ & $51-60$ & $1.0-3$ & $60-78$ & $1.0-3$ \\
\hline AGE & $26-30 Y$ & & $31-35 Y$ & & $36-40 Y$ & & $41-45 Y$ & & $>45$ & \\
\hline WEIGHT & BW (Kg) & WI (L) & BW $(\mathrm{Kg})$ & WI (L) & BW (Kg) & WI (L) & BW (Kg) & WI (L) & BW (Kg) & WI (L) \\
\hline UPFARMS & $63-90$ & $1.0-5$ & $65-90$ & $1.0-5$ & $65-90$ & $1-5 L$ & $60-105$ & $1.0-4$ & $60-90$ & $1-3 L$ \\
\hline SASSE & $60-80$ & $1.0-5$ & $45-92$ & $1.0-3$ & $77-85$ & $2.0-5$ & $70-85$ & $1.0-3$ & $64-85$ & $2.0-5$ \\
\hline TOLE & $60-72$ & $1.0-5$ & $60-90$ & $1.0-4$ & $65-91$ & $1.5-5$ & $70-82$ & $1.0-5$ & $60-85$ & $1.0-3$ \\
\hline SANDPIT & $63-84$ & $1.0-5$ & $60-90$ & $2.0-5$ & $75-80$ & $1.0-2$ & $65-102$ & $1.0-5$ & $60-95$ & $2.0-5$ \\
\hline BONDUMA & $60-75$ & $1.0-5$ & $62-76$ & $1.0-5$ & $60-83$ & $1.0-5$ & $65-95$ & $1.0-4$ & $67-80$ & $1.0-5$ \\
\hline BWITEVA & $60-85$ & $1.0-3$ & $65-85$ & $1.0-5$ & $60-85$ & $1.0-5$ & $55-95$ & $1.0-5$ & $55-80$ & $1.0-2$ \\
\hline MUEA & $58-77$ & $1.5-3$ & $60-87$ & $1.0-5$ & $65-95$ & $2.0-5$ & $65-84$ & $1.0-5$ & $63-70$ & $1.0-3$ \\
\hline MILE 16 & $64-72$ & $1.0-3$ & $60-80$ & $1.0-5$ & $60-83$ & $1.0-5$ & $64-90$ & $1.0-5$ & $68-85$ & $1.5-2$ \\
\hline EKONA & $65-86$ & $1.0-3$ & $63-80$ & $1.0-5$ & $62-75$ & $2.0-4$ & $65-95$ & $1.0-5$ & $65-85$ & $1.0-4$ \\
\hline MAUTU & $60-98$ & $1.0-5$ & $62-77$ & $1.0-5$ & $60-82$ & $1.0-5$ & $65-92$ & $1.0-5$ & $60-90$ & $2.0-5$ \\
\hline
\end{tabular}

Table 5. Trace metal concentration and basic statistics of groundwater in study area.

\begin{tabular}{|c|c|c|c|c|c|c|c|c|c|c|c|c|c|c|c|}
\hline Location & $\mathrm{N}$ & $\mathrm{E}$ & $\mathrm{Zn} \mu \mathrm{g} / \mathrm{L}$ & $\mathrm{Pb} \mu \mathrm{g} / \mathrm{L}$ & $\mathrm{Co} \mu \mathrm{g} / \mathrm{L}$ & $\mathrm{Cu} \mu \mathrm{g} / \mathrm{L}$ & $\mathrm{Cr} \mu \mathrm{g} / \mathrm{L}$ & $\mathrm{Mn} \mu \mathrm{g} / \mathrm{L}$ & $\mathrm{Cd} \mu \mathrm{g} / \mathrm{L}$ & $\mathrm{V} \mu \mathrm{g} / \mathrm{L}$ & $\mathrm{Fe} \mu \mathrm{g} / \mathrm{L}$ & $\mathrm{Ni} \mu \mathrm{g} / \mathrm{L}$ & As $\mu \mathrm{g} / \mathrm{L}$ & $\mathrm{Sb} \mu \mathrm{g} / \mathrm{L}$ & $\mathrm{Al} \mu \mathrm{g} / \mathrm{L}$ \\
\hline Upfarms & 9.223 & 4.162 & 8.5 & 0.74 & 0.06 & 1.7 & 0.7 & 4.3 & 0.06 & 4 & 20 & 0.6 & 0.04 & 0 & 17 \\
\hline Sasse & 9.228 & 4.109 & 19.7 & 0.31 & 0.03 & 1.1 & 1.2 & 1.9 & 0.02 & 9.5 & 5 & 0.7 & 0.15 & 0 & 11 \\
\hline Tole & 9.238 & 4.111 & 44.3 & 0.4 & 0.07 & 1.2 & 1 & 2.9 & 0.11 & 10.7 & 20 & 0.7 & 0.18 & 0 & 32 \\
\hline Sandpit & 9.259 & 4.143 & 31.6 & 0.32 & 0.04 & 0.8 & 1.1 & 2.1 & 0.01 & 12.8 & 10 & 0.4 & 0.11 & 0 & 9 \\
\hline Bonduma & 9.272 & 4.160 & 9.1 & 0.18 & 0.14 & 1 & 0.9 & 3.1 & 0.01 & 7.2 & 5 & 0.5 & 0.08 & 0 & 9 \\
\hline Bwiteva & 9.278 & 4.173 & 13.6 & 0.22 & 0.05 & 1 & 1.1 & 2.8 & 0.01 & 13.3 & 5 & 0.5 & 0.2 & 0 & 9 \\
\hline Muea & 9.292 & 4.167 & 17.7 & 0.21 & 0.07 & 1 & 1.2 & 5.2 & 0.02 & 13.7 & 5 & 0.6 & 0.15 & 0 & 6 \\
\hline Mile 16 & 9.309 & 4.144 & 26.4 & 0.28 & 0.11 & 1.8 & 1.7 & 5.9 & 0.02 & 17.2 & 5 & 0.6 & 0.2 & 0 & 12 \\
\hline Ekona & 9.338 & 4.236 & 18 & 0.26 & 0.04 & 1.7 & 1 & 1.9 & 0.01 & 13.8 & 30 & 0.4 & 0.19 & 0 & 14 \\
\hline Mautu & 9.366 & 4.259 & 13.3 & 0.23 & 0.03 & 1 & 1.1 & 1.4 & 0.01 & 15.3 & 5 & 0.5 & 0.16 & 0 & 8 \\
\hline \multicolumn{3}{|c|}{ Min } & 8.5 & 0.18 & 0.03 & 0.8 & 0.7 & 1.4 & 0.01 & 4 & 5 & 0.4 & 0.04 & 0 & 6 \\
\hline \multicolumn{3}{|c|}{ Max } & 44.3 & 0.74 & 0.14 & 1.8 & 1.7 & 5.9 & 0.11 & 17.2 & 30 & 0.7 & 0.2 & 0 & 32 \\
\hline \multicolumn{3}{|c|}{ Mean } & 21.25 & 0.34 & 0.07 & 1.24 & 1.12 & 3.23 & 0.03 & 11.56 & 12.08 & 0.55 & 0.14 & 0 & 13.75 \\
\hline \multicolumn{3}{|c|}{ WHO limit } & 3000 & 10 & 10 & 2000 & 50 & 400 & 3 & 200 & 2000 & 70 & 10 & 20 & 200 \\
\hline
\end{tabular}


study area. Average concentrations of these elements were in the decreasing order as follows in mg/l: $\mathrm{Zn} \mathrm{(0.0202),} \mathrm{Fe} \mathrm{(0.02),} \mathrm{Al} \mathrm{(0.0127),} \mathrm{V} \mathrm{(0.0117),} \mathrm{Mn}$ (0.0032), $\mathrm{Cu}$ (0.00123), Cr (0.0011), Ni (0.00055), Pb (0.00032), As (0.00015), Co (0.0000666), Cd (0.0000325), Sb (0.000024). Zn, Pb, Co, Cu, Cr, Mn, V, Ni, As, $\mathrm{Sb}$ and $\mathrm{Al}$ were detected in all the groundwater samples. The highest concentration of trace metal found in the study area was of $\mathrm{Zn}$ with a maximum of 44.3 $\mu \mathrm{g} / \mathrm{L}$ detected at Tole.

\subsection{Pearson's Correlation Analysis (PCA) between Trace Metals}

Correlation between trace metals in groundwater within the study area was carried out using Pearson's correlation analysis (PCA) shown in Table 6, to establish the relationships that exist between the variables; trace metals and the physicochemical parameters in Table 2. $r$ values $>0.5$ or $<-0.5$ are significant, 0.72 strong (moderate) and 0.80 Very strong correlation.

In Table 6, a very strong positive correlation exists between the following; $\mathrm{Fe}$ and $\mathrm{Cu}(\mathrm{r}=0.843), \mathrm{Fe}$ and $\mathrm{Sb}(\mathrm{r}=0.816), \mathrm{Cr}$ and $\mathrm{V}(\mathrm{r}=0.778), \mathrm{Cd}$ and $\mathrm{Al}(\mathrm{r}=$ $0.930), \mathrm{V}$ and As $(\mathrm{r}=0.817), \mathrm{V}$ and EC $(\mathrm{r}=0.867), \mathrm{V}$ and $\mathrm{PH}(\mathrm{r}=0.718), \mathrm{V}$ and TDS $(r=0.867)$, V and temperature $(r=0.724)$, As and EC $(r=0.749)$, As and TDS $(r=0.749)$, EC and TDS $(r=1)$, TDS and PH $(r=0.753) \mathrm{PH}$ and temperature $(r=0.807)$, TDS and temperature $(r=0.734)$. Moderately positive correlation exists between the following:

Table 6. Correlation matrix of $\mathbf{r}$ values for trace metals and physico-chemical parameters in study area.

\begin{tabular}{|c|c|c|c|c|c|c|c|c|c|c|c|c|c|c|c|c|c|}
\hline Element & $\mathrm{Zn}$ & $\mathrm{Pb}$ & Co & $\mathrm{Cu}$ & $\mathrm{Cr}$ & $\mathrm{Mn}$ & $\mathrm{Cd}$ & V & $\mathrm{Fe}$ & $\mathrm{Ni}$ & As & $\mathrm{Sb}$ & $\mathrm{Al}$ & $\mathrm{EC}$ & $\mathrm{pH}$ & TDS & Temp \\
\hline $\mathrm{Zn}$ & 1 & & & & & & & & & & & & & & & & \\
\hline $\mathrm{Pb}$ & 0.01 & 1 & & & & & & & & & & & & & & & \\
\hline Co & -0.06 & -0.14 & 1 & & & & & & & & & & & & & & \\
\hline $\mathrm{Cu}$ & -0.06 & 0.47 & 0.17 & 1 & & & & & & & & & & & & & \\
\hline $\mathrm{Cr}$ & 0.32 & -0.47 & 0.17 & 0.14 & 1 & & & & & & & & & & & & \\
\hline $\mathrm{Mn}$ & -0.01 & 0.19 & 0.62 & 0.44 & 0.41 & 1 & & & & & & & & & & & \\
\hline $\mathrm{Cd}$ & 0.52 & 0.56 & -0.02 & 0.13 & -0.30 & 0.05 & 1 & & & & & & & & & & \\
\hline V & 0.30 & -0.64 & -0.15 & -0.02 & 0.78 & 0.06 & -0.32 & 1 & & & & & & & & & \\
\hline $\mathrm{Fe}$ & -0.36 & -0.11 & -0.07 & 0.84 & -0.24 & -0.07 & 0.00 & 0.09 & 1 & & & & & & & & \\
\hline $\mathrm{Ni}$ & 0.28 & 0.31 & 0.15 & 0.13 & 0.16 & 0.36 & 0.60 & -0.26 & 0.00 & 1 & & & & & & & \\
\hline As & 0.40 & -0.57 & -0.19 & 0.08 & 0.65 & -0.05 & 0.02 & 0.82 & 0.47 & 0.04 & 1 & & & & & & \\
\hline $\mathrm{Sb}$ & 0.15 & 0.46 & -0.11 & 0.40 & -0.42 & 0.24 & 0.53 & -0.26 & 0.82 & 0.20 & -0.10 & 1 & & & & & \\
\hline $\mathrm{Al}$ & 0.64 & 0.49 & 0.04 & 0.32 & -0.25 & -0.01 & 0.93 & -0.28 & 0.21 & 0.47 & 0.08 & 0.52 & 1 & & & & \\
\hline $\mathrm{EC}$ & 0.08 & -0.80 & -0.18 & -0.28 & 0.47 & -0.17 & -0.46 & 0.87 & 0.17 & -0.51 & 0.75 & -0.27 & -0.40 & 1 & & & \\
\hline $\mathrm{pH}$ & 0.36 & -0.86 & 0.34 & -0.31 & 0.64 & 0.16 & -0.21 & 0.72 & 0.00 & -0.08 & 0.68 & -0.26 & -0.17 & 0.74 & 1 & & \\
\hline TDS & 0.08 & -0.80 & -0.18 & -0.28 & 0.47 & -0.17 & -0.46 & 0.87 & 0.17 & -0.51 & 0.75 & -0.27 & -0.40 & 1.00 & 0.74 & 1 & \\
\hline Temp & 0.06 & -0.91 & 0.20 & -0.16 & 0.58 & -0.12 & -0.55 & 0.72 & 0.29 & -0.33 & 0.58 & -0.39 & -0.38 & 0.73 & 0.81 & 0.73 & 1 \\
\hline \multicolumn{7}{|c|}{$r$ values $>0.5$ or $<-0.5$ are significant } & \multicolumn{5}{|c|}{$r>0.72$ Strong correlation } & \multicolumn{6}{|c|}{$r>0.80$ Very strong correlation } \\
\hline
\end{tabular}


$\mathrm{Zn}$ and $\mathrm{Al}(\mathrm{r}=0.642)$, Co and $\mathrm{Mn}(\mathrm{r}=0.615), \mathrm{Cr}$ and $\mathrm{As}(\mathrm{r}=0.648), \mathrm{Cr}$ and $\mathrm{PH}(\mathrm{r}=0.638)$, $\mathrm{Cd}$ and $\mathrm{Ni}(\mathrm{r}=0.604)$, As and $\mathrm{PH}(\mathrm{r}=0.677)$ and Very strong negative correlation exist between $\mathrm{Pb}$ and $\mathrm{EC}(\mathrm{r}=-0.8), \mathrm{Pb}$ and $\mathrm{PH}(\mathrm{r}=-0.859)$, $\mathrm{Pb}$ and TDS $(\mathrm{r}=0.8), \mathrm{Pb}$ and temperature $(\mathrm{r}=-0.906)$. A moderately negative correlation exists for $\mathrm{Pb}$ and $\mathrm{V}(\mathrm{r}=-0.641)$.

A high correlation coefficient (nearly 1 or -1 ) means a good relationship between two variables, and a correlation coefficient around zero means no relationship. Positive values indicate a positive relationship while negative values of $r$ indicate an inverse relationship [33].

The very strong negative correlation between $\mathrm{Pb}$ and $\mathrm{pH}$ is an indication that $\mathrm{Pb}$ concentrations increase with decreasing $\mathrm{pH}$, as such $\mathrm{Pb}$, has a strong negative correlation with TDS and EC [34]. This is similar to the correlation between Al and $\mathrm{Cd}$, also $\mathrm{Fe}$ and $\mathrm{Cu}$.

\subsection{Hierarchical Cluster Analysis HCA}

The R-mode Cluster Analysis CA performed on the samples produced two clusters based on spatial similarities and dissimilarities: Cluster 1; comprised Co, Cd, $\mathrm{Sb}, \mathrm{As}, \mathrm{Pb}, \mathrm{Ni}, \mathrm{Cr}, \mathrm{Cu}$ and $\mathrm{Mn}$ which were less soluble and cluster 2; $\mathrm{Fe}, \mathrm{Al}, \mathrm{V}$ and $\mathrm{Zn}$ which were more soluble within the ionic content, $\mathrm{pH}, \mathrm{EC}$ and temperature range of groundwater and of this region shown in Figure 3. The relative

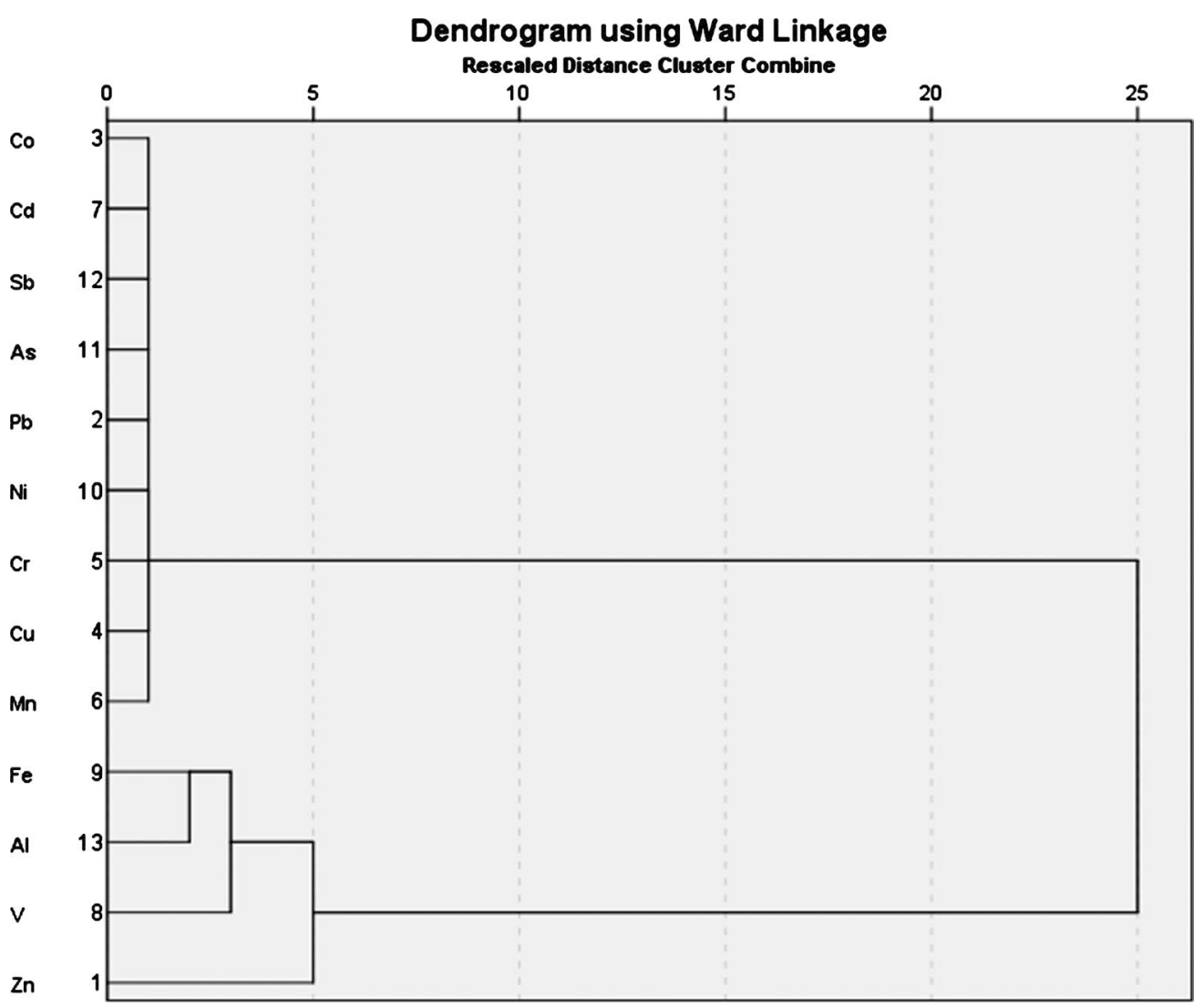

Figure 3. Dendrogram of trace metals in groundwater of the study area made up of two clusters: Cluster one (09) elements $\mathrm{Co}, \mathrm{Cd}, \mathrm{Sb}, \mathrm{As}, \mathrm{Pb}, \mathrm{Ni}, \mathrm{Cr}, \mathrm{Cu}, \mathrm{Mn}$ and cluster two; (04) elements; $\mathrm{Fe}, \mathrm{Al}, \mathrm{V}, \mathrm{Zn}$. 
elevated concentrations of the cluster two elements $(\mathrm{Fe}, \mathrm{Al}, \mathrm{V}$ and $\mathrm{Zn})$ is due to the ease with which they can be dissolved into solution within the EC, $\mathrm{pH}$ and temperature ranges found in the study area [35].

\subsection{Health Risk Assessment ADD, HQ, CR, HI}

Human health risk assessment was done to measure or estimate the intensity, frequency, and duration of human exposures to an environmental contaminant. Exposure assessment was carried out by measuring the average daily dose ADD of the trace metals selected, Table 6 . The sample population was divided according to ten age groups Table 3. Due to behavioural and physiological differences. Carcinogenic and non carcinogenic risk were calculated from the ADD.

$\mathrm{ADD}$ values ranged as follows; $3.4 \times 10^{-7}$ to $7.4 \times 10^{-6}(\mathrm{As}), 3.6 \times 10^{-7}$ to $2.8 \times$ $10^{-6}(\mathrm{Sb}), 1.6 \times 10^{-4}$ to $3.1 \times 10^{-3}(\mathrm{Al}), 7.4 \times 10^{-6}$ to $6.7 \times 10^{-5}(\mathrm{Ni}), 1.8 \times 10^{-7}$ to $2.9 \times 10^{-5}(\mathrm{Cd}), 7.2 \times 10^{-7}$ to $2.3 \times 10^{-5}(\mathrm{Co}), 1.4 \times 10^{-5}$ to $1.2 \times 10^{-4}(\mathrm{Cr}), 3.9 \times$ $10^{-5}$ to $4.1 \times 10^{-4}(\mathrm{Mn}), 1.7 \times 10^{-4}$ to $4.2 \times 10^{-3}(\mathrm{Zn}), 3.6 \times 10^{-6}$ to $4.5 \times 10^{-5}(\mathrm{~Pb})$, $1.5 \times 10^{-5}$ to $1.3 \times 10^{-4}(\mathrm{Cu}), 3.4 \times 10^{-5}$ to $5.1 \times 10^{-4}(\mathrm{~V}), 7.9 \times 10^{-5}$ to $8.6 \times 10^{-4}$ $(\mathrm{Fe})$ as seen in Figure 4.

HQ values ranged as follow; $2.8 \times 10^{-3}$ to $2.5 \times 10^{-2}$ (As), $8.9 \times 10^{-7}$ to $7.2 \times$ $10^{-6}(\mathrm{Sb}), 2.3 \times 10^{-5}$ to $4.3 \times 10^{-4}(\mathrm{Al}), 3.7 \times 10^{-4}$ to $3.3 \times 10^{-3}(\mathrm{Ni}), 3.7 \times 10^{-4}$ to $5.8 \times 10^{-2}(\mathrm{Cd}), 3.6 \times 10^{-5}$ to $1.1 \times 10^{-3}(\mathrm{Co}), 4.6 \times 10^{-3}$ to $3.9 \times 10^{-2}(\mathrm{Cr}), 6.4 \times$ $10^{-6}$ to $2.9 \times 10^{-3}(\mathrm{Mn}), 1.5 \times 10^{-4}$ to $1.4 \times 10^{-2}(\mathrm{Zn}), 6.7 \times 10^{-4}$ to $1.2 \times 10^{-2}(\mathrm{~Pb})$, $2.9 \times 10^{-3}$ to $2.5 \times 10^{-2}(\mathrm{Cu}), 8.9 \times 10^{-2}$ to $0.5(\mathrm{~V}), 1.1 \times 10^{-4}$ to $1.2 \times 10^{-3}(\mathrm{Fe})$ as shown in Figure 5.

$\mathrm{CR}$ for the carcinogenic elements; $\mathrm{Pb}, \mathrm{Cr}, \mathrm{Cd}, \mathrm{Ni}$ and $\mathrm{As}$ are; $(\mathrm{Pb}) 1.4 \times 10^{-8}$ to $6.7 \times 10^{-6},(\mathrm{Cr}) 2.9 \times 10^{-6}$ to $2.5 \times 10^{-5}$, (Cd) $3.0 \times 10^{-8}$ to $1.7 \times 10^{-6}$, (Ni) $2.3 \times$ $10^{-6}$ to $4.9 \times 10^{-5}$, (As) $5.1 \times 10^{-7}$ to $1.1 \times 10^{-5}$ shown in Figure 6 .

$\mathrm{HI}$ is the cumulative sum of HQ. The values ranged between 0.1 and 0.6 for each of the ten (10) age groups indicating no toxicity as in Figure 7.

The 0 - 5 years age range had the most elevated ADD values followed by 6 - 10 year age range, consenquently the $\mathrm{HQ}, \mathrm{HI}$ and $\mathrm{CR}$ values were relatively higher for these age ranges but were well below 1 indicating an acceptable level and the exposed population is unlikely to experience adverse health effects. This is due to a higher water intake to body weight ratio which would imply a higher risk for children 0 - 10 years old to trace metal cumulative contamination; In Tole for

Table 7. Parameters used for estimating exposure assessment [24].

\begin{tabular}{cccc}
\hline Factor/parameter & Symbol & Units & Residential \\
\hline Exposure duration & ED & Years & 30 \\
Exposure frequency & EF & Days in year & 350 \\
Average time & AT & Years & 76.5 \\
Body weight & BW & Kg & Table 3 \\
Ingestion rate & IR & L/day & Table 3 \\
Contaminant concentration & C & ug/L & Table 4
\end{tabular}



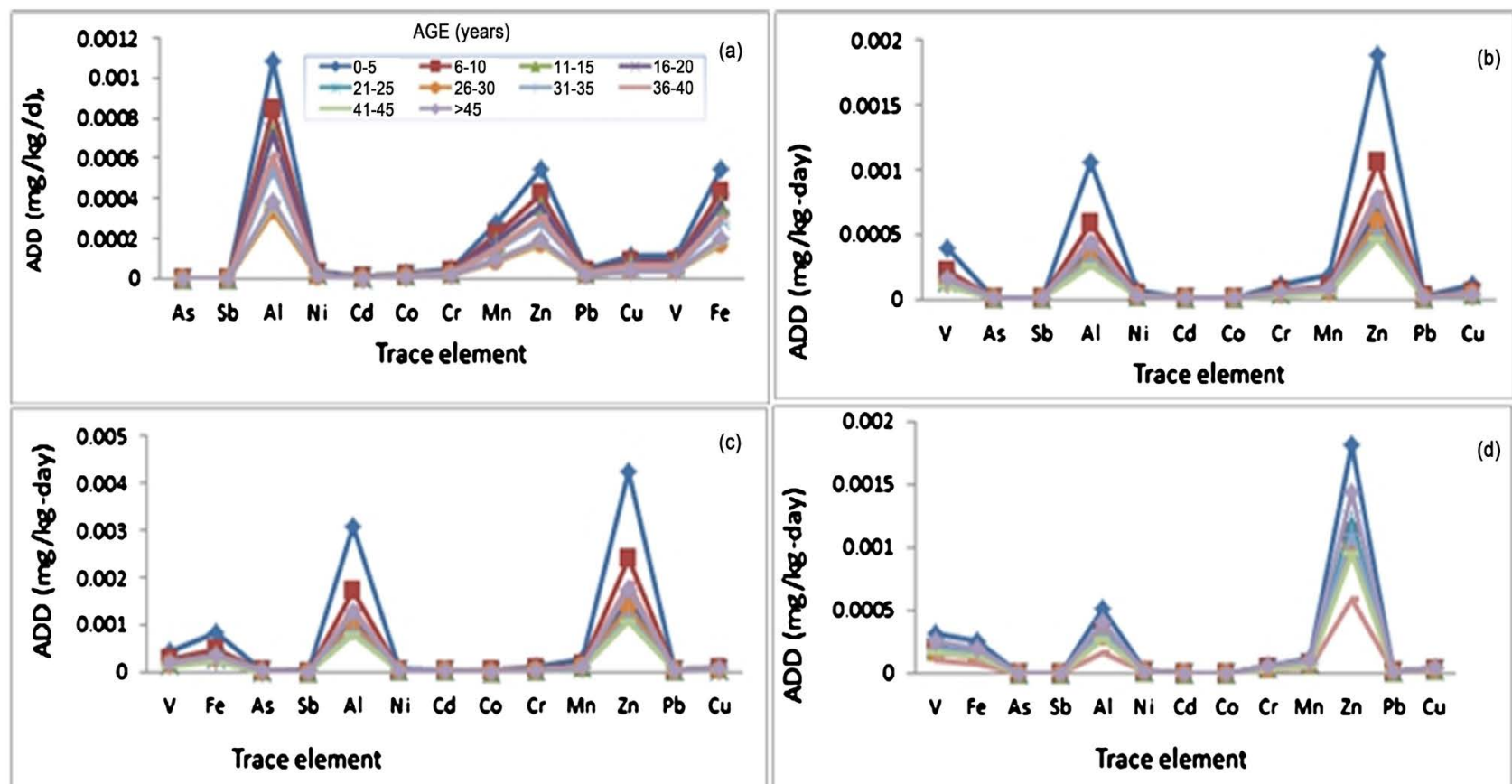

Trace element
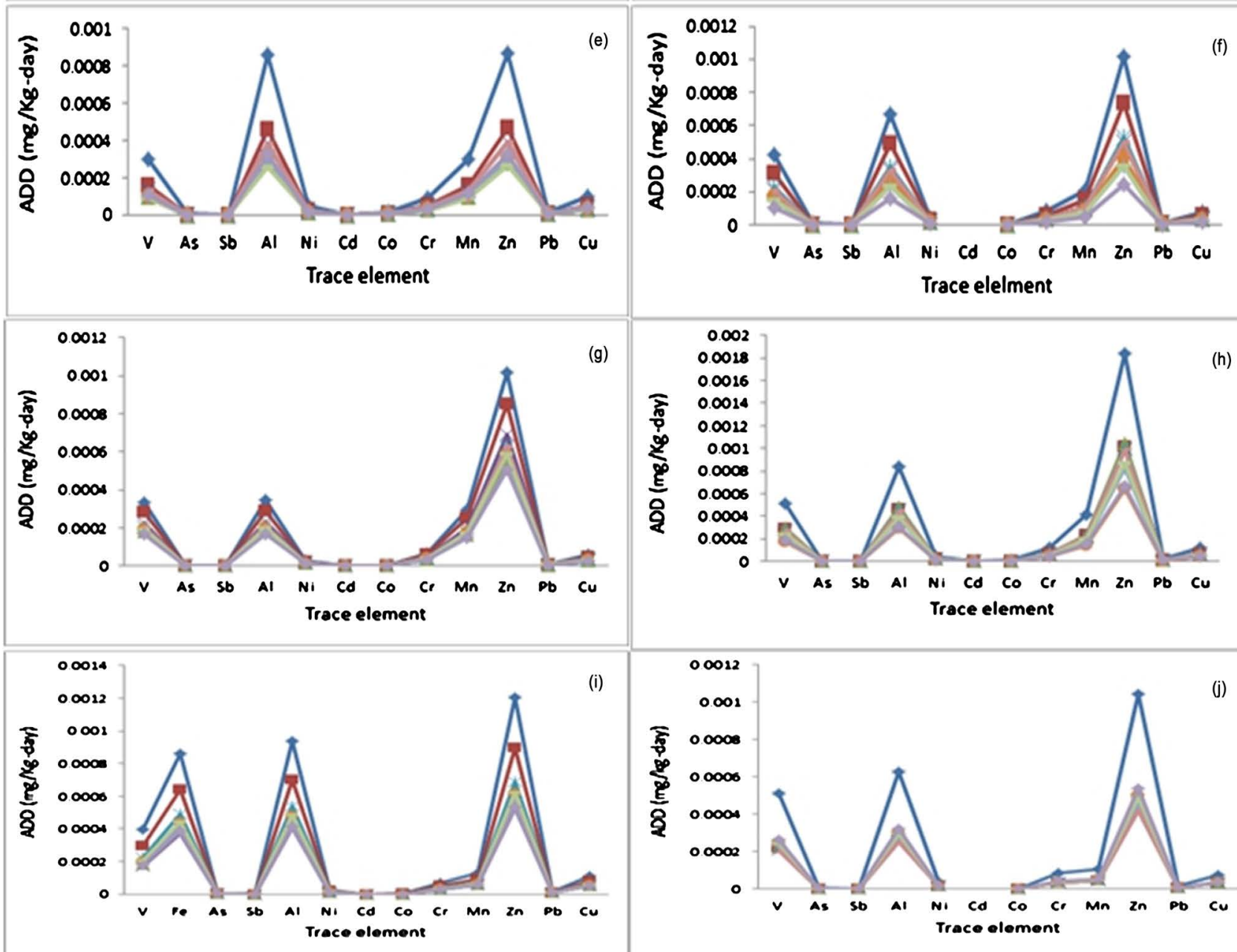

Figure 4. Average Daily Dose (ADD) of each contaminant for each of the ten (10) age groups water intake. All values are below toxic level. 

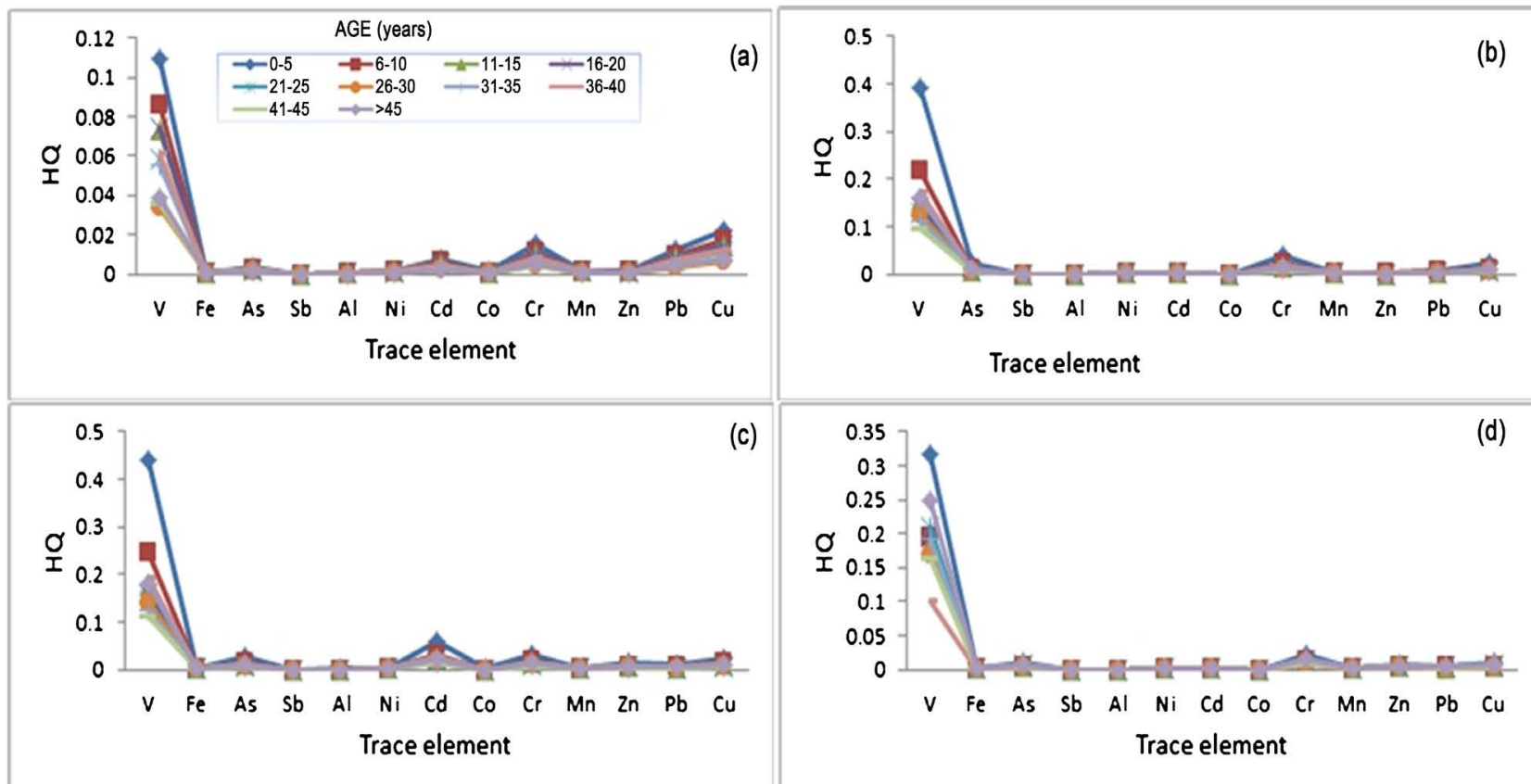

Trace element
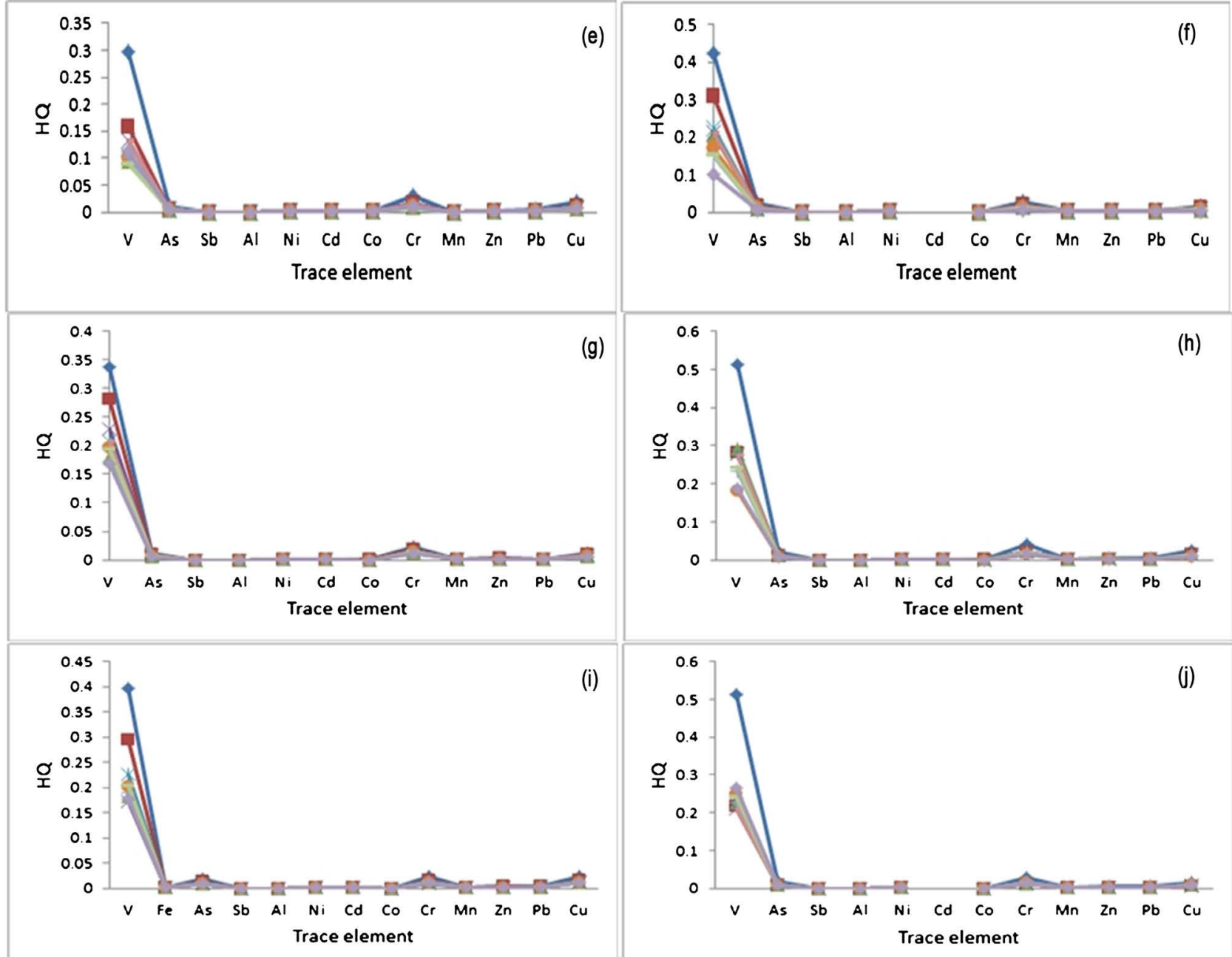

Figure 5. Non-carcinogenic hazards; hazard quotient (HQ) of each contaminant for each of the ten (10) age groups through water intake. All values are below toxic levels. 

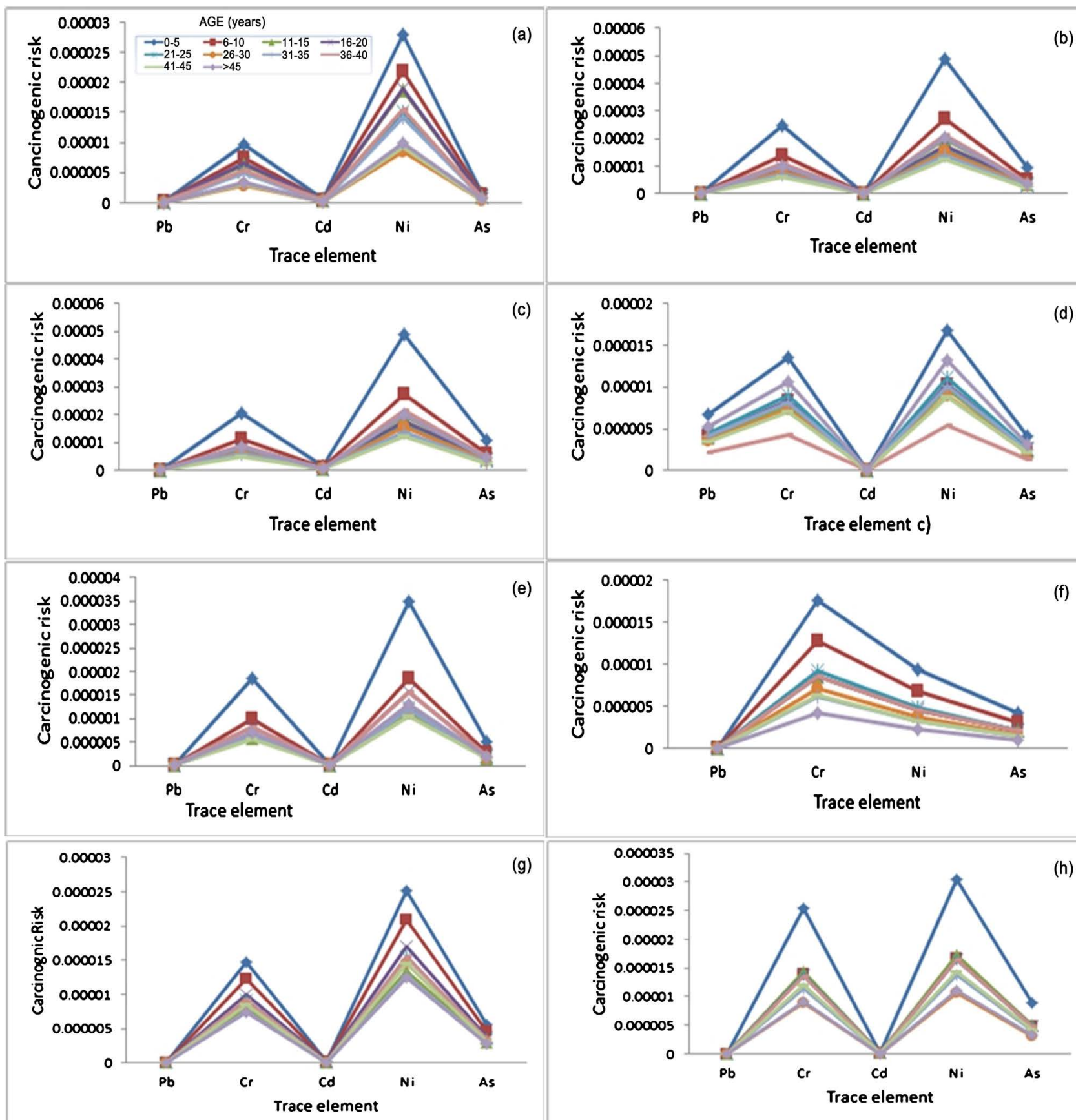

(g)
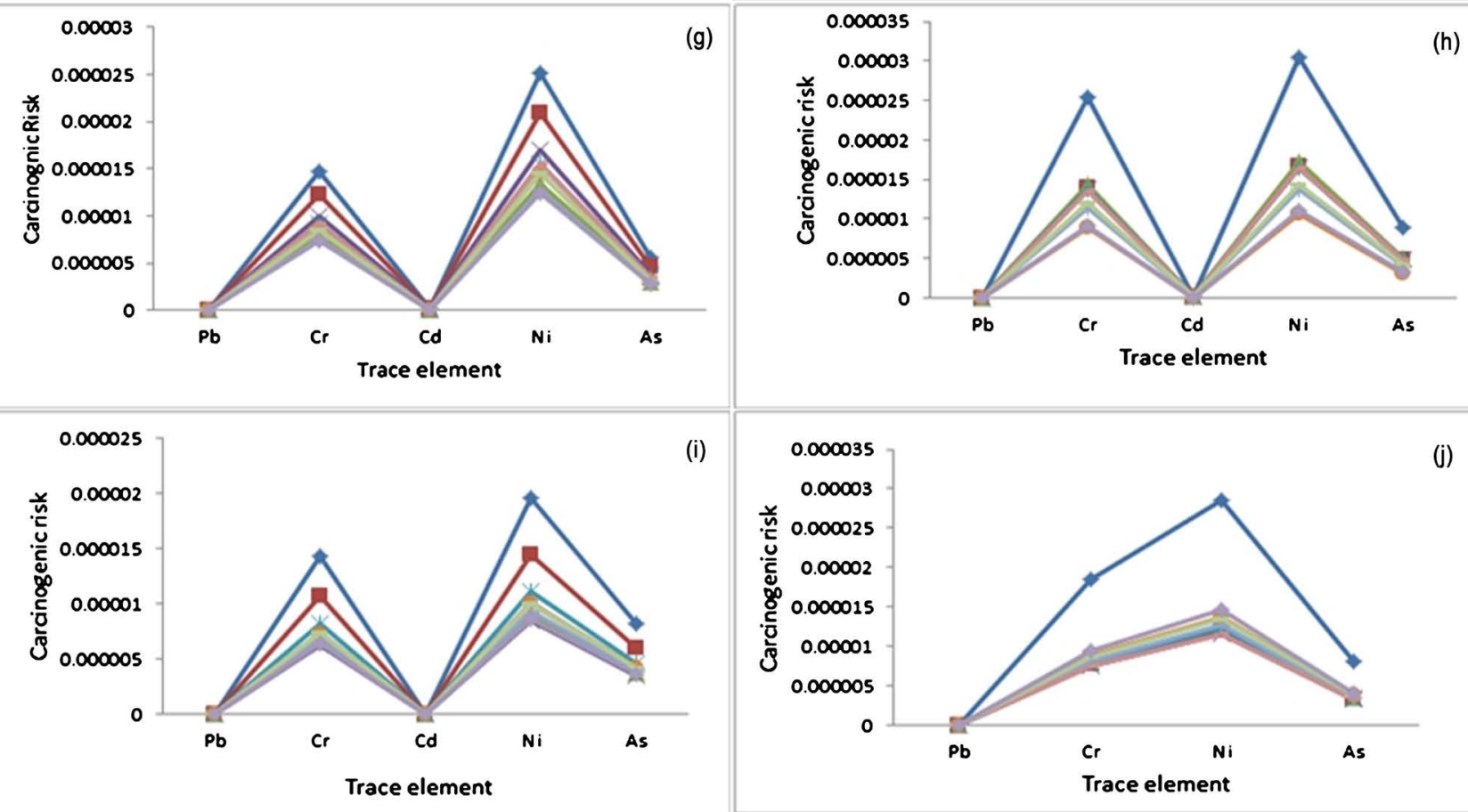

Figure 6. Carcinogenic risk (CR) of each contaminant for each of the ten (10) age groups water. All values are below toxic levels. 


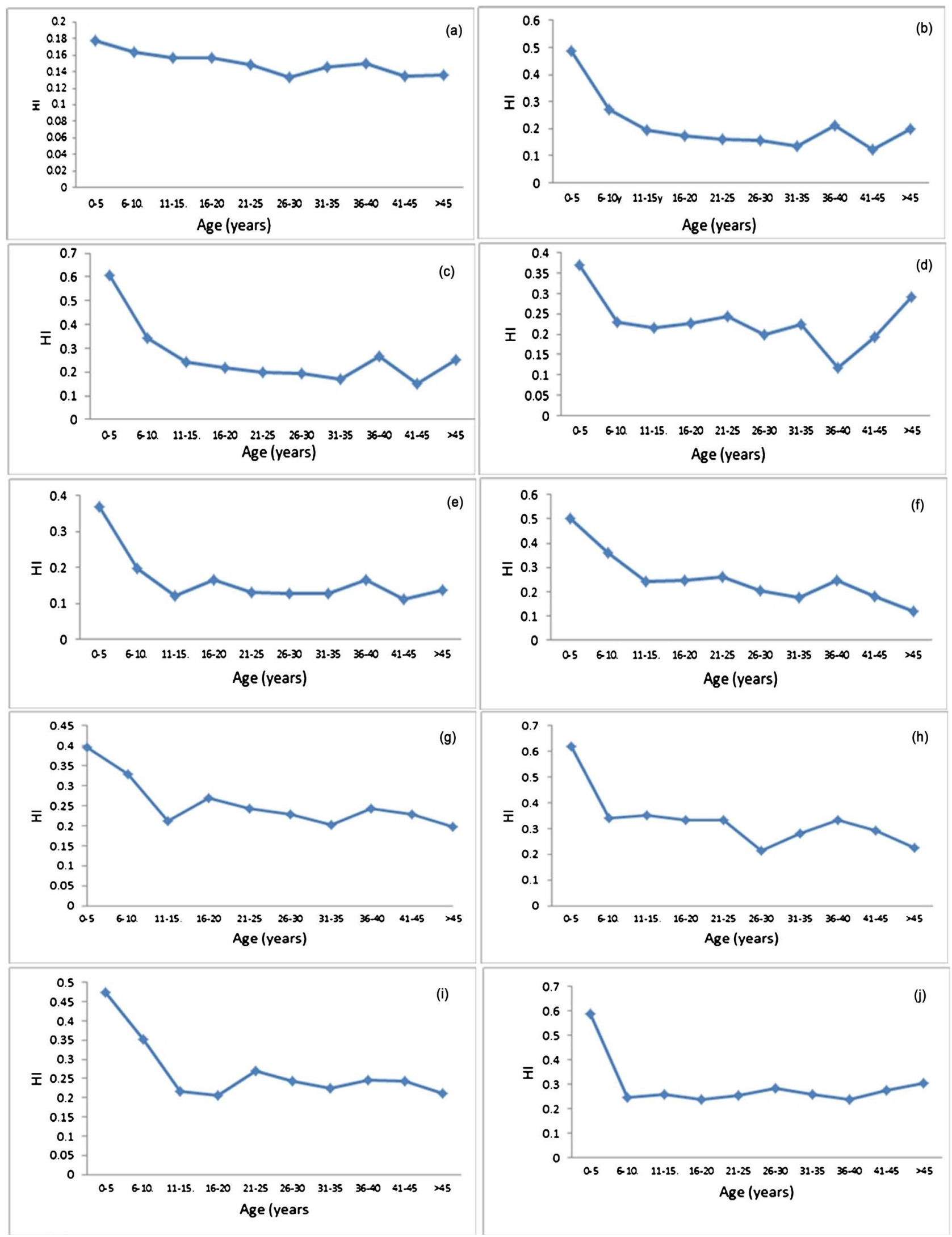

Figure 7. Non carcinogenic toxic risk index or hazard index (HI) of each contaminant for each of the ten (10) age groups water intake. All values are below toxic levels. 
example, the maximum weight of infants 0 - 5 years was $12 \mathrm{~kg}$, of adults $41-45$ was $82 \mathrm{~kg}$ while their water intake max was 2.0 and 5.0 litres respectively. Giving an intake body weight ratio of 2/12 (24\%) for infants and 5/82 (4.1\%) for adults respectively, a (24/4.1) six times higher trace metal intake cumulative contamination ratio for this two groups in Tole.

$\mathrm{Pb}$ and $\mathrm{Cd}$ values were less than $1 \times 10^{-6}$ and are not regarded as to cause significant health effects. $82.5 \%$ of $\mathrm{Cr}$ values are regarded as not to cause significant health effects and $17.5 \%$ regarded generally as in the satisfactory range. $21 \%$ of $\mathrm{Ni}$ values are regarded as not to cause significant health effects $79 \%$ are regarded generally as satisfactory range. For As, $99 \%$ of values are not regarded as significant to cause health effects and $1 \%$ regarded as satisfactory presented in Table 8 .

Increased water demand due to unprecedented population growth and urbanization has led to serious water supply crisis within the Piedmont Regions of Mount Cameroon. This has compelled many inhabitants to rely mostly on springs as sources for drinking water. To ascertain the suitability of these alternative groundwater sources for human consumption, an assessment of the heavy metal content was requisite.

\section{Conclusions}

The trace metal concentrations in this region are low. There low trace metal concentrations have been attributed to the geology; absence of rocks containing high concentrations of trace metals, the slightly acidic to neutral $\mathrm{pH}$, low temperatures $<25^{\circ} \mathrm{C}$ and the short residence time of ground water, conditions necessary for trace metal oxidation, dissolution and precipitation in groundwater.

Although other studies around Mt. Cameroon postulated anomalous concentrations of arsenic in water on the plains of the leeward side of Mount Cameroon [2] and another determined high concentrations in the soils [3] on the windward side of Mt. Cameroon respectively, this study has found no anomalous concentration of any trace metal in the groundwater.

Health risk assessment $\mathrm{ADD}, \mathrm{CR}, \mathrm{HQ}$ and $\mathrm{HI}$ of the groundwater sources in this area were within the standard permisible limits indicating an acceptable level.

Table 8. Classification of health risk assessment carcinogenic and non-carcinogenic risk).

\begin{tabular}{ccccc}
\hline INDEX & Range & Classification & $(\%)$ & Source \\
\hline \multirow{2}{*}{$\mathrm{CR}$} & $<10^{-6}$ & cause no significant health effects & 82.5 & \\
& $>10^{-6}-10^{-4}<$ & Generally satisfactory & 17.5 & {$[36]$} \\
& $>10^{-4}$ & Intolerable & NA & \\
HQ & $<1$ & Acceptable level (no concern) & 100 & \\
& $>1$ & No carcinogenic adverse effects & NA & {$[24]$} \\
HI & $<1$ & Safe & 100 & \\
& $>1$ & Unsafe & NA & {$[24]$} \\
\hline
\end{tabular}


The exposed population is therefore unlikely to experience immediate adverse health effects from consuming groundwater in the Piedmont region of Mt. Cameroon.

However, monitoring is recommended due to the rapid increase in population and activities of agro-industrial complexes in this region that are using various fertilizers and insecticides.

\section{Acknowledgements}

We sincerely thank all the field workers and the respondents to questionnaires for their time.

\section{Funding}

This research did not receive any specific grant from funding agencies in the public, commercial, or not-for-profit sectors.

\section{Submission Declaration and Verification}

The submission of this article implies that the work described here-in has not been published previously and that it is not under consideration for publication elsewhere; that this publication has been approved by all authors and tacitly or explicitly by the responsible authorities where the work was carried out, and that, if accepted, it will not be published elsewhere in the same form, in English or in any other language, including electronically without the written consent of the copyright holder.

\section{Highlights}

- Trace elements in groundwater of a volcanic terrain;

- Health Risk assessment;

- Water resources evaluation;

- Groundwater Physico-chemical quality;

- Piedmont regions of Mount Cameroon-Africa.

\section{Conflicts of Interest}

The authors declare no conflicts of interest regarding the publication of this paper.

\section{References}

[1] Ako, A.A., Shimada, J., Hosono, T., Kagabu, M., Akoachere, A.R., Nkeng, G.E., Eyong, G.E.T. and Takounjou, A.L.F. (2012) Spring Water Quality and Usability in the Mount Cameroon Area Revealed by Hydrogeochemistry. Environmental Geochemistry and Health, 34, 615-639. https://doi.org/10.1007/s10653-012-9453-3

[2] Mbotake, I.T. (2006) A Preliminary Study of Sources of Arsenic Contamination in Southwest Cameroon. Journal of Environmental Hydrogeology, 14, 1-11.

[3] Manga, V.E., Agyingi, C.M. and Suh, C.E. (2014) Trace Metal Soil Quality Status of 
Mt. Cameroon Soils. Advances in Geology, 2014, Article ID: 894103. https://doi.org/10.1155/2014/894103

[4] Mehri, A. and Marjan, R.F. (2013) Trace Metals in Human Nutrition: A Review. International Journal of Medical Investigation, 2, 115-128.

[5] Marschner, H. (1995) Mineral Nutrition of Higher Plants. Academic Press, London.

[6] Verma, R. and Dwivedi, P. (2013) Heavy Metal Water Pollution-A Case Study. Recent Research in Science and Technology, 5, 98-99.

[7] Anake, W.U., Benson, N.U., Akinsiku, A.A., Ehi-Eromosele, C.O. and Adeniyi, I.O. (2014) Assessment of Trace Metals in Drinking Water and Groundwater Sources in Ota, Nigeria. International Journal of Scientific and Research Publications, 4, 1-4.

[8] Folifac, F., Lifongo, L., Nkeng, G. and Gaskin, S. (2009) Municipal Drinking Water Source Protection in Low Income Countries: Case of Buea Municipality Cameroon. Journal of Ecology and Natural Environment, 1, 73-84.

[9] Che, V.B., Kervyn, M., Suh, C.E., Fontijn, K., Ernst, G.G.J., del Marmol, M.A., Trefois, O. and Jacobs, P. (2012) Landslide Susceptibility Assessment in Limbe (SW Cameroon): A Field Calibrated Seed Cell and Information Value Method. Catena, 92, 83-98. https://doi.org/10.1016/j.catena.2011.11.014

[10] Vanloon, G.W. and Duffy, S.J. (2005) The Hydrosphere. In: Environmental Chemistry: A Global Perspective, 2nd Edition, Oxford University Press, New York, 197-211.

[11] Adepoju-Bello, A.A., Ojomolade, O.O., Ayoola, G.A. and Coker, H.A.B. (2009) Quantitative Analysis of Some Toxic Metals in Domestic Water Obtained from Lagos Metropolis. Nigerian Journal of Pharmaceutical Research, 42, 57-60.

[12] Buea Council (2015) United Councils and Cities of Cameroon.

[13] Fraser, P.J. and Hall, J.B. (1998) Climate of the Mount Cameroon Region: Long and Medium Term Rainfall, Temperature and Sunshine Data. School of Agricultural and Forest Sciences, University of Wales, Bangor, Gwynedd.

[14] Endeley, R.N., Ayonghe, S.N. and Tchuenteu, F. (2001) A Preliminary Hydrogeochemical and Baseline Study of Water Sources around Mount Cameroon. Journal of the Cameroon Academy of Sciences, 1, 127-185.

[15] Akoachere, R., Itie, M., Yaya, O. and Oteze, G. (2006) Morphometric Analysis of the Piedmont Regions of Mount Cameroon, West Africa. In: J. Nig. Ass. Hydrogeologist, Ed., American Water Works Association (2011) Water Resource Planning: Manual of Water Supply Practices, Quincy Avenue, Denver, 131.

[16] Orock, F.T. (2006) Analysis of the Degradation of Springs and Streams from Perched Aquifers on the Eastern and Southern Slopes of Mount Cameroon. Unpublished MSc Thesis, University of Buea-Cameroon, Buea.

[17] Buea Council (2005) Management of Water in Buea Council. ECTI Commission Report of June 2005.

[18] Suh, C.E., Sparks, R.S.J., Fitton, J.G., Ayonghe, S.N., Annen, C., Nana, R. and Luckman, A. (2003) The 1999 and 2000 Eruptions of Mount Cameroon: Eruption Behaviour and Petrochemistry of Lava. Bulletin of Volcanology, 65, 267-281. https://doi.org/10.1007/s00445-002-0257-7

[19] Fitton, J.G. and Dunlop, H.M. (1985) The Cameroon Line, West Africa, and Its Bearing on the Origin of Oceanic and Continental Alkali Basalt. Earth and Planetary Science Letters, 72, 23-38. https://doi.org/10.1016/0012-821X(85)90114-1

[20] Deruelle, B., Ngounouno, I. and Demaiffe (2007) The "Cameroon Hot Line" (CHL): A Unique Example of Active Alkaline Intraplate Structure in Both Oceanic and 
Continental Lithospheres. Geoscience, 339, 589-600. https://doi.org/10.1016/j.crte.2007.07.007

[21] Ngongang, A.W. (2016) Seismic and Volcanological Hazard Analysis of Mount Cameroon Volcano. University of Pretoria, Pretoria, 1-70.

[22] Dumort, J.C. (1967) Caractères chimiques des trois volcanismes du Cameroun. Bulletin B.R.G.M.

[23] Tsafack, J.P.F., Wandji, P., Bardintzeff, J.M. and Nkouathio, D.G. (2007) Occurrence of a Sedimentary Basement under the Mount Cameroon Active Volcano (Cameroon Volcanic Line). 26th ECGS, Luxembourg, 19-21 November 2007.

[24] USEPA (2012) Waste and Clean up Risk Assessment. http://www2.epa.gov/risk/waste-and-cleanup-risk-assessment

[25] Lushenko, M.A. (2010) A Risk Assessment for Ingestion of Toxic Chemicals in Fish from Imperial Beach. San Diego State University, San Diego.

[26] Ayantobo, O.O., Awomeso, J.A., Oluwasanya, G.O., Bada, B.S. and Taiwo, A.M. (2014) Non-Cancer Human Health Risk Assessment from Exposure to Heavy Metals in Surface and Groundwater in Igun Ijesha, Southwest Nigeria. https://doi.org/10.3844/ajessp.2014.301.311

[27] Kolluru, R.V., Bartell, S.M., Pitblado, R.M. and Stricoff, R.S. (1996) Risk Assessment and Management Handbook. McGraw-Hill, New York.

[28] Paustenbach, D.J. (2002) Human and Ecological Risk Assessment: Theory and Practice. John Wiley and Sons, New York.

[29] WHO (2011) Guidelines for Drinking-Water Quality. 1-541.

[30] Hu, X., Zhang, Y., Ding, Z.H, Wang, T.J., Lian, H.Z. and Sun, Y.Y. (2012) Bio-Accessibility and Health Risk of Arsenic and Heavy Metals (Cd, Co, Cr, Cu, Ni, $\mathrm{Pb}, \mathrm{Zn}$ and $\mathrm{Mn}$ ) in TSP and PM2.5 in Nanjing, China. Atmospheric Environment, 57, 146-152. https://doi.org/10.1016/j.atmosenv.2012.04.056

[31] Koki, I.B., Bayero, A.S., Umar, A. and Yosuf, S. (2015) Health Risk Assessment of Heavy Metals in Water, Air, Soil and Fish. African Journal of Pure and Applied Chemistry, 9, 204-210. https://doi.org/10.5897/AJPAC2015.0654

[32] Kamunda, C., Mathuthu, M. and Madhuku, M. (2016) Health Risk Assessment of Heavy Metals in Soils from Witwatersrand Gold Mining Basin, South Africa. International Journal of Environmental Research and Public Health, 13, pii: E663. https://doi.org/10.3390/ijerph13070663

[33] Song, D., Zhuang, D., Jiang, D., Fu, J. and Wang, Q. (2015) Integrated Health Risk Assessment of Heavy Metals in Suxian County, South China. International Journal of Environmental Research and Public Health, 12, 7100-7117. https://doi.org/10.3390/ijerph120707100

[34] Kim, E.J., Herrera, J.E., Huggins, D., Braam, J. and Koshowki, S. (2011) Effect of pH on the Concentrations of Lead and Trace Contaminants in Drinking Water: A Combined Batch, Pipe Loop and Sentinel Home Study. Water Research, 45, 2763-2774. https://doi.org/10.1016/j.watres.2011.02.023

[35] Fijalkowski, K., Kacprzak, M., Grobelak, A. and Placek, A. (2012) The Influence of Selected Soil Parameters on the Mobility of Heavy Metals in Soils. Inżynieria $i$ Ochrona Środowiska, 15, 81-92.

[36] Edet, A.E. and Offiong, O.E. (2002) Evaluation of Water Quality Pollution Indices for Heavy Metal Contamination Monitoring: A Study Case from Akpabuyo-Odukpani Area Lower Cross River Basin (Southeastern Nigeria). GeoJournal, 57, 295-304. https://doi.org/10.1023/B:GEJO.0000007250.92458.de 